\title{
A sympathetic struggle
}

\author{
Mohammed Abid Yusuf
}

Received: 13 January 2015 / Accepted: 5 February 2015 / Published online: 14 February 2015

(C) Springer-Verlag Berlin Heidelberg 2015

In all the workings of the beautiful form

Our bodies take in all their variety

One never ceases to be struck with wonder

At why the system might avoid propriety.

It mobilises its garrisons at even the slightest hint

Of an external attack from microbes in rows

The assumption made that it will register its own men

And spare them the wrath meted out upon its foes.

Ask then the man with synovium battered and bruised

What enemy is being defended against here?

Ask then the pained woman with joints eroded

Why her own form makes her shed that tear.

Outside oppression is softened by a sympathetic ear

Eager to share in our pain and to care

The internal struggles are harder to bear

With sympathy wearing thin, friendly faces so rare.

In their support then we work and strive

Lending help to those struggling on in their daily pain

It's in their comfort that we find our inner drive

Knowing full well that our efforts are never in vain.

Conflict of interest None.

M. A. Yusuf $(\bowtie)$

Core Medical Trainee, Basildon University Hospital,

Nethermayne, Basildon SS16 5NL, UK

e-mail: abidyusuf@doctors.org.uk 